\title{
PENGARUH VARIASI METERING STROKE TERHADAP CACAT PRODUK CETAKAN INJEKSI PLASTIK
}

\author{
Rahman Hakim ${ }^{1}$, Amar Makruf ${ }^{2}$, Ahmad Nurasa $^{3}$, Widodo4, Irvan Wahyudi ${ }^{5}$ \\ 1,4,5Politeknik Negeri Batam. Jl. Ahmad Yani Kota Batam, Kepulauan Riau \\ ${ }^{2,3}$ PT. EPSON Batam. Batamindo Industrial Park, J1. Rambutan Lot no. 504-508A, Kabil, Kecamatan \\ Nongsa, Kota Batam, Kepulauan Riau \\ Email: ${ }^{1}$ hakim@ @olibatam.ac.id, ${ }^{2}$ amarmakruf2203@gmail.com, ${ }^{3}$ hmd.nurasa@gmail.com, \\ ${ }^{4}$ widodo@polibatam.ac.id, 5 irvanwhydi@gmail.com
}

\begin{abstract}
Abstrak
Penelitian ini bertujuan untuk menganalisis pengaruh metering stroke terhadap kualitas produk. Metering stroke berhubungan dengan berat produk dan kapasitas cetakan. Material yang digunakan adalah Polyamide (Nylon) 66, dengan menggunakan mesin Injection Molding ENGEL berkapasitas 50ton. Metode penelitian yang digunakan adalah metode eksperimental sebelum praproduksi massal dengan variasi pengukuran langkah sebagai parameter produksi. Uji normalitas digunakan untuk menyelidiki data eksperimen. Rumus Shapiro-Wilk pada software Minitab ${ }^{\circledR}$ digunakan untuk mengolah data. Cacat produk yang disebabkan oleh metering stroke yang tidak tepat sering kali dalam proses injeksi adalah short-mold dan flashing. Hasil penelitian menunjukkan bahwa cacat produksi short-mold terjadi pada saat metering stroke $60 \mathrm{~mm}$ akibat material tidak memenuhi rongga penuh. Selain itu, flashing terjadi saat langkah pengukuran $70 \mathrm{~mm}$ karena kapasitas rongga cetakan tidak mampu menampung volume plastic yang berlebih. Oleh karena itu, parameter yang sesuai adalah metering stroke sebesar 65 mm dengan kualitas hasil bagian yang baik.
\end{abstract}

Keywords: Metering Stroke, Nylon 66, Cetakan Injeksi Plastik, Cacat Produk

\begin{abstract}
The research aims to analyze the effect of metering stroke on product quality. Metering strokes relate to product weight and mold capacity. The material used is Polyamide (Nylon) 66, using an ENGEL 50ton capacity Injection Molding machine. The research method used is an experimental method before mass pre-production with stroke metering variation as a production parameter. A normality test was used to investigate the experimental data. ShapiroWilk's formula on Minitab ${ }^{\circledR}$ software was used to process the data. Product defects caused by an improper metering stroke often in the injection process are short mold and flashing prints. The results show that short mold production defects occur when the metering stroke is $60 \mathrm{~mm}$ due to the material does not fill the full cavity. Furthermore, flashing occurs when the metering stroke is $70 \mathrm{~mm}$ due to out of cavity capacity. Therefore, the appropriate parameter is a $65 \mathrm{~mm}$ metering stroke with good quality part results.
\end{abstract}

Keywords: Metering Stroke, Nylon 66, Plastic Injection Mold, Product Defects

\section{PENDahuluan}

Banyak produk yang ada disekitar kita yang terbuat dari bahan plastic, mempunyai sifat mudah dibentuk, ringan, anti korosif, digunakan kembali, dan murah. Oleh karena itu, plastik merupakan salah satu bahan virgin dengan pengguna terbanyak di dunia. Hampir semua produk yang kita jumpai dalam kehidupan sehari-hari terbuat dari bahan plastik (Firdaus \& Tjitro, 2002).

Terdapat beberapa proses pengolahan bahan plastik, salah satunya dengan metode injection 
moulding. Mesin injection moulding adalah salah satu mesin yang digunakan untuk mengolah butiran plastik, yang menggunakan proses pra-pemanasan. Sebuah screw-barrel pada cetakan injeksi dipanaskan sampai titik leleh sesuai dengan bahan yang digunakan, kemudian dicetak dan didinginkan dalam sebuah ruangan yang disebut cetakan (Hakim, 2020).

Menurut Siallagan (2018), kualitas kekasaran permukaan pada mold-insert berbahan baku baja ASTM P20 mempunyai hubungan yang positif dengan kualitas permukaan produk (Siallagan, Restu, \& Hakim, 2018). Kualitas permukaan semimirror pada mold-insert juga harus memiliki kekuatan mekanik dan sifat termal lebih dari baja karbon ST 37 (Wijayanti, Hakim, \& Widodo, 2019), serta mempunyai gaya kompresi dan perpindahan panas yang lebih baik (Jahan et al., 2017).

Sheave merupakan salah satu dari jenis katrol yang biasanya digunakan untuk menarik layar pada kapal layar, baik berupa tali, hingga kawat baja sebagai pengikat. Sebaliknya, part yang digunakan dalam penelitian ini adalah Cheeck-S55-BB yang merupakan penutup sheave sisi bagian dalam.

Selain berfungsi sebagai penutup bagian dalam katrol, bagian ini juga harus mempunyai sifat fisik seperti bahan anti korosif. Menurut Yalcin (2004), kriteria fisika material: geser tinggi - thermal gradient yang tinggi juga merupakan faktor pendukung utama dalam unit sheave yang beroperasi secara optimal untuk material nilon 66 nanokomposit (Yalcin \& Cakmak, 2004).

Berdasarkan fungsi part di atas, perlu diproduksi dengan tingkat akurasi, kepadatan, dan porositas yang tinggi. Parameter tersebut dikontrol dengan ketat dan merupakan proses yang sangat baik untuk menjalankan fungsinya dengan tingkat kegagalan mekanis serendah mungkin (Wahyudi, 2015). Pengaturan system manufaktur sangat penting terutama pada saat work-shifting mengalami perubahan saat mengganti cetakan baru. Proses pemanasan mesin dengan melakukan shoot clearance dan pengaturan parameter guna menjaga kualitas produksi sesuai dengan standar (Izdihar, Budiman, \& Ananto, 2019).

Untuk mendapatkan produk berkualitas yang bebas dari campuran dan kotoran selama produksi sebelumnya atau menghindari cacat produksi seperti berkedip dan berjamur pendek (Moayyedian, Abhary, \& Marian, 2015). Untuk lebih jelasnya, pada Gambar 1 terdapat visualisasi dari product defect.

Menurut Nuruzzaman (2016), short-mold adalah suatu kondisi dimana kapasitas lelehan plastik tidak dapat memenuhi kapasitas volume cetakan (Nuruzzaman, Kusaseh, Basri, Oumer, \& Hamedon, 2016). Sedangkan menurut Mehdi Moayyedian (2018), Flash merupakan suatu kondisi dimana cacat yang terlihat dan ditandai dengan adanya tumpahan plastik yang melebihi rongga. Sehingga untuk memperbaikinya harus melalui proses pemotongan bagian plastik yang berlebih (Moayyedian, 2018). Untuk lebih jelasnya visualisasi dari product defect terdapat pada gambar 7, yang dilengkapi dengan hubungan sebab-akibat yang ditimbulkannya.

Penelitian ini bertujuan untuk menentukan pengaturan parameter yang tepat pada pengaturan metering stroke untuk cacat produksi jenis flashes dan short-mold melalui metode studi eksperimental. Pengumpulan data dilakukan tujuh kali untuk setiap pengaturan parameter, mengingat waktu yang singkat dan terbatas sebelum produksi massal.

Menurut Chou (2018), Akurasi penyusutan, short-mold, diselidiki karena signifikansi parameter langkah pengukuran pada bahan HDPE dengan metode optimasi six sigma melalui pendekatan DMAIC. (Chou \& Chen, 2018).

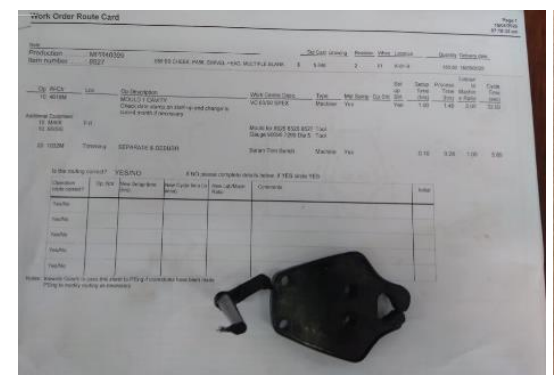

(a)

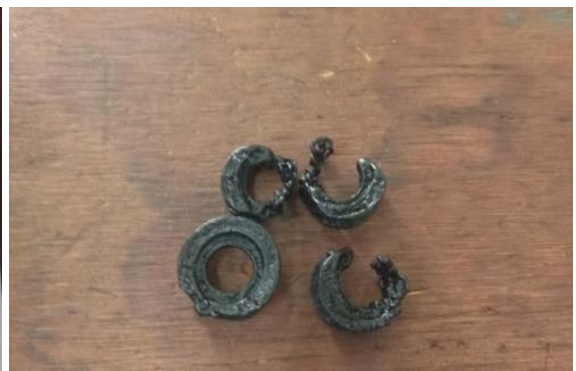

(b)

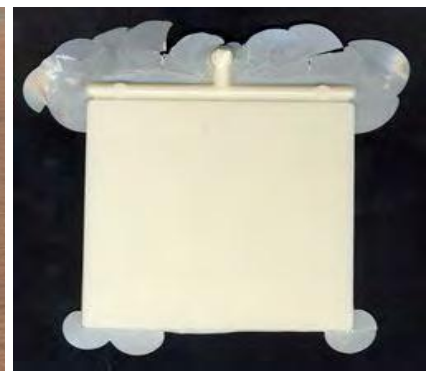

(c)

Gambar 1. (a) Produk jadi: inner-side sheave cover, Jenis cacat produksi; (b) Short-Mold, (c) Flashes. 


\section{METODOLOGI PENELITIAN}

\section{a. Fasilitas}

Mesin yang digunakan adalah Engel Victory Molding Machine dengan kapasitas mesin 50 ton dengan spesifikasi komponen mesin yang tertera, seperti terlihat pada Tabel I.

Tabel 1. Spesifikasi Teknis Mesin Cetakan Plastik (ENGEL 50T) beserta Peralatan Pendukungnya

\begin{tabular}{|c|c|c|}
\hline Equipment & Specification & Function \\
\hline $\begin{array}{l}\text { Injection molding } \\
\text { machine ENGEL }\end{array}$ & 50ton & $\begin{array}{c}\text { Injection } \\
\text { machine } \\
(2011)\end{array}$ \\
\hline Chiller TT-188E & Up to $150^{\circ} \mathrm{C}$ & Cooling system \\
\hline Mold Set & One cavity & $\begin{array}{l}\text { Molding the } \\
\text { product }\end{array}$ \\
\hline Hopper dryer & $45 \mathrm{Kg}$ & $\begin{array}{l}\text { Dry the } \\
\text { material }\end{array}$ \\
\hline
\end{tabular}

Bahan plastik yang digunakan dalam penelitian ini adalah nilon 66. Spesifikasi teknis dari bahan nilon 66 tercantum pada Tabel 2.

Tabel 2. Data Teknis dari Bahan Nylon 66 (Young, 1990)

\begin{tabular}{lc}
\hline Mechanical Properties & Value \\
\hline Physical & \\
Density $\left(\mathrm{gr} / \mathrm{cm}^{3}\right)$ & 1,35 \\
Water saturation $(\%)$ & 5.4 \\
Mechanical & \\
Yield stress $($ KPSI) & 27 \\
Tensile modulus $($ KPSI) & 140 \\
Thermal & \\
Melting point $\left({ }^{\circ} \mathrm{C}\right)$ & 255 \\
Flammability rating & $\mathrm{HB}$ \\
Mold Temperature $\left({ }^{\circ} \mathrm{C}\right)$ & $80-90$ \\
Drying Temperature $\left({ }^{\circ} \mathrm{C}\right)$ & $80(60-120)$ \\
Drying Time $($ Hours $)$ & $3-4$ \\
\hline
\end{tabular}

\section{b. Perhitungan Dasar}

Parameter gerak langkah ulir atau yang paling kita kenal sebagai metering stroke, menentukan volume bahan yang akan disuntikkan ke dalam cetakan yang mempengaruhi berat produk. Misalnya pada proses pembuatan produk dapat ditentukan sejauh mana stroke metering menggunakan rumus (Moayyedian, 2018).

$$
\begin{aligned}
& C=\pi \times R s^{2} \times L \\
& K=\rho \times n
\end{aligned}
$$

$W=C \times K$

Selanjutnya $C$ adalah Shoot capacity $\left(\mathrm{cm}^{3}\right)$ yang dipengaruhi oleh Ds $(18 \mathrm{~cm})$ atau Diameter screw (cm) dengan $L$ atau Langkah Injeksi (Screw) $(\mathrm{cm})$. Shoot weight $(W)$ (gr / shot), bersama-sama dengan $\rho$ atau masa jenis lelehan plastik pada temperatur cetakan ( $\mathrm{gr} / \mathrm{cm} 3$ ), dan $n$ atau koefisien nilai efisiensi dari check ring $(0,90$ - 0,95), menjadi salah satu faktor pendukung dari perhitungan metering stroke. Menurut Young, nilai $K$ atau konstanta konduktivitas termal sebesar 0,95. (Young, 1990).

\section{c. Prosedur Pelaksanaan Eksperimen}

Pra-Pemanasan: Manfaat ketika memanaskan Nylon 66 adalah material akan mencapai suhu cetakan lebih cepat dan mengurangi siklus waktu pemrosesan. Kemudian bisa menghilangkan kadar air sebelum bahan ditempatkan ke dalam cetakan. (Bryce, 1996). Parameter pemanasan material pada hopper dapat dilihat pada Tabel III..

Tabel 3. Data Parameter Pengaturan - Hopper

\begin{tabular}{lc}
\hline Material & Nylon 66 \\
Pre-heating temperature & $100^{\circ} \mathrm{C}$ \\
Pre-heating time & 3 hours \\
Hopper brand & Shini (Japan) \\
\hline
\end{tabular}

Pengaturan Suhu Barrel: Barrel disetel sesuai dengan jenis bahan yang digunakan. Pada pengujian ini material yang digunakan adalah Poliamida (Nylon) 66, dengan temperatur operasi ditunjukkan pada Gambar 2. Heater nomor tiga dan dua diatur $270^{\circ} \mathrm{C}$ dan $275^{\circ} \mathrm{C}$ untuk memulai proses pemanasan. Kemudian heater nomor satu di setel $290^{\circ} \mathrm{C}$ untuk mencegah terjadinya penyumbatan sebelum masuk ke area nozzle. Konduktivitas termal pada area cetakan, suhu akan menurun. Oleh karena itu, pemanas nozzel mengatur $290^{\circ} \mathrm{C}$ untuk mempertahankan titik leleh Nylon 66 pada $255^{\circ} \mathrm{C}$.

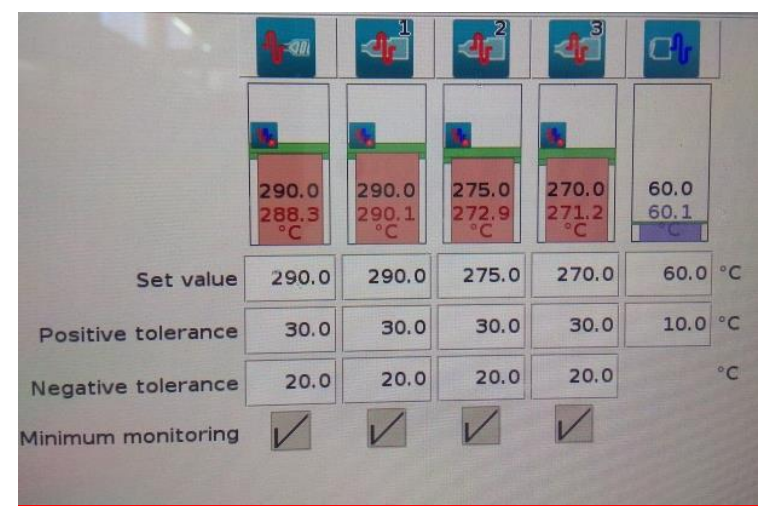

Gambar 2. Barrel Setup Display Pada Mesin ENGLE 50-Ton 
Jika lampu sakelar menyala dan material siap untuk diinjeksi, operator dapat melihat kesiapan material pada mesin berdasarkan nilai temperatur pada data bagian bawah pada tampilan barrel setup pada gambar 2.

Mesin Pengatur Panas Cetakan Plastik: Mesin pemanas (Alat pengatur suhu) pada gambar 3 yang digunakan adalah tipe TT-188 E dengan maksimum $150^{\circ} \mathrm{C}$ dan nilai yang ditetapkan $80^{\circ} \mathrm{C}$. Tujuan pengontrol suhu alat adalah untuk menjaga suhu pada area cetakan.

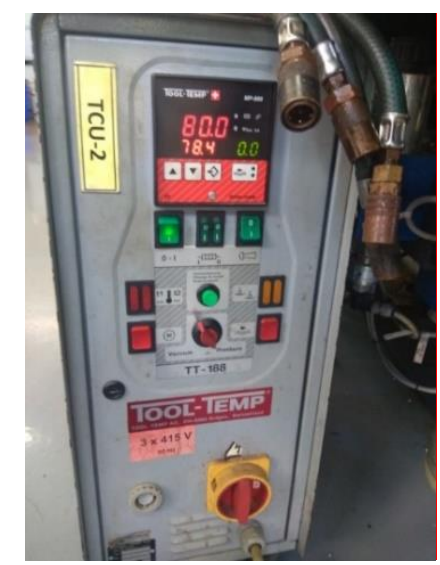

Gambar 3. Tool Temperature Controller Machine

Parameter Pengaturan Metering Stroke: Data parameter pengaturan panjang stroke (Gambar 4) yang akan dilakukan dalam pengujian terdapat tiga variasi jumlah pengukuran stroke. Berdasarkan data perancangan dan perhitungan (Persamaan 1) pada cetakan injeksi volume rongga masing-masing nilai pengujian adalah $60 \mathrm{~mm}, 65 \mathrm{~mm}$, dan $70 \mathrm{~mm}$.

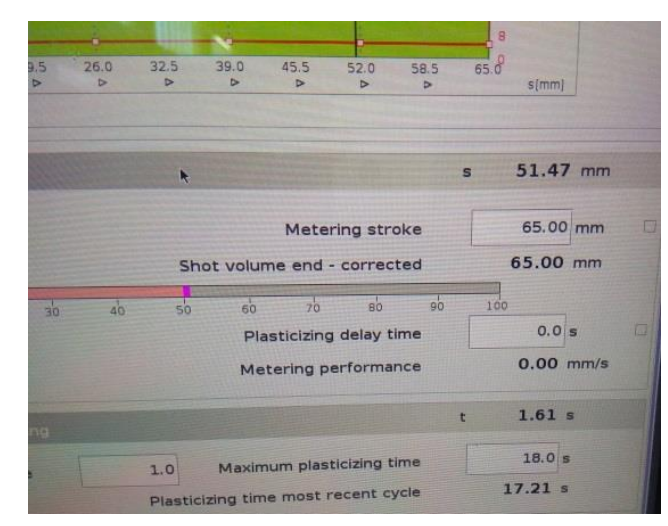

Gambar 4. Pengaturan Metering Stroke

Pengamatan Hasil Percobaan: Setelah menjalankan mesin injeksi pada mode semi otomatis, jalankan satu kali per produk, dan menganalisa produk pada setiap jumlah langkah variasi pengukuran yang telah dilakukan.

Setelah menjalankan pengujian semi otomatis setiap satu tembakan, akan dilakukan hasil observasi pada setiap parameter yang divariasikan dan direkam. Hasil produk akan difoto untuk mengetahui pengaruh variasi parameter langkah pengukuran.

Metode evaluasi statistik, uji normalitas, digunakan untuk menyelidiki data eksperimen. Rumus Shapiro-Wilk pada software Minitab $^{\circledR}$ digunakan untuk mengolah data.

Kriteria keberhasilan studi eksperimental ini didasarkan pada pemeriksaan kualitas visual dari bagian dalam penutup sheave. Tidak ada cacat shortmold dan flashes. Pengukuran berat dan dimensi kritis harus memenuhi toleransi. Dimensi kritis diukur dengan menggunakan Go / No-Go (Hole Test) dan jangka sorong terlebih dahulu. Dalam studi eksperimental ini, hanya melakukan pengukuran bobot dan inspeksi kualitas visual.

\section{HASIL DAN PEMBAHASAN}

Distribusi data normalitas dan data eksperimen telah dilakukan. Pada gambar 5a, menggunakan rumus Shapiro-Wilk menghasilkan P-Value lebih dari 0,1 yang berarti sebaran data berdistribusi normal karena nilai minimumnya 0,05 .

Distribusi data berat material bagian ditampilkan pada data box plot pada Gambar 5b. $\mathrm{P}_{1}$ mewakili parameter metering stroke sebesar $60 \mathrm{~mm}$ dengan berat rata-rata 19,514 gr dan deviasi standar 0,348. $\mathrm{P}_{2}$ mewakili metering stroke sebesar $65 \mathrm{~mm}$ dengan berat rata-rata 20,801 gr dan deviasi standar 0,658. $\mathrm{P}_{3}$ merepresentasikan metering stroke sebesar $70 \mathrm{~mm}$ dengan berat rata-rata 21.759 gr dan deviasi standar 0.428 .

Gambar 6 menjelaskan perbedaan antara nilai rata-rata data eksperimen dan data hasil perhitungan. Pada parameter metering stroke sebesar $60 \mathrm{~mm}$, selisih antara data hasil perhitungan dan data eksperimen adalah 25,71\%. Kemudian, pada parameter metering stroke sebesar $65 \mathrm{~mm}$, selisih antara data perhitungan dan data eksperimen adalah $24,5 \%$. Selain itu, perbedaan parameter metering stroke sebesar $70 \mathrm{~mm}$ antara data perhitungan dan data eksperimen adalah $22,27 \%$. 


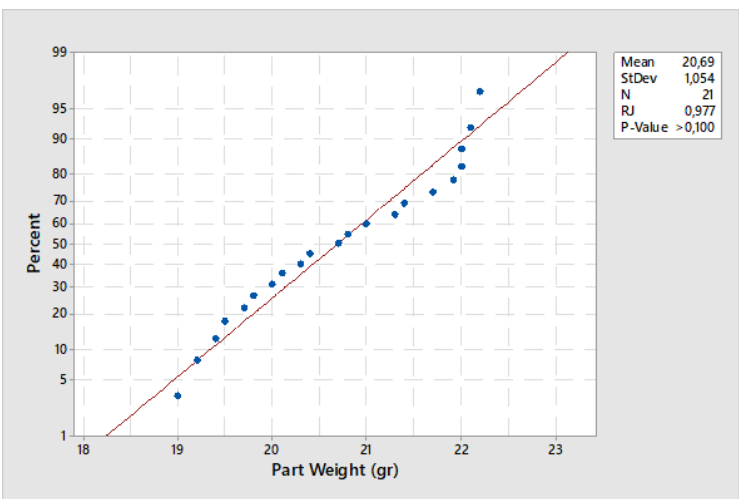

(a)

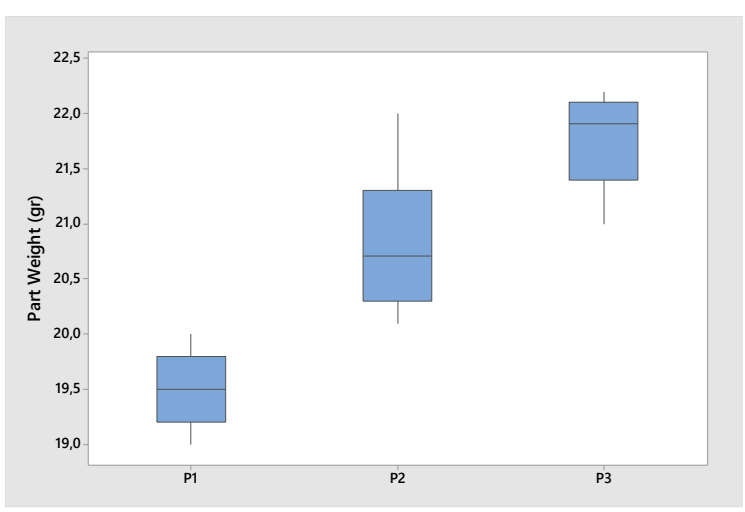

(b)

Gambar 5. Pola Sebaran Data Penelitian, (a) Normality Test, (b) Box Plot Data

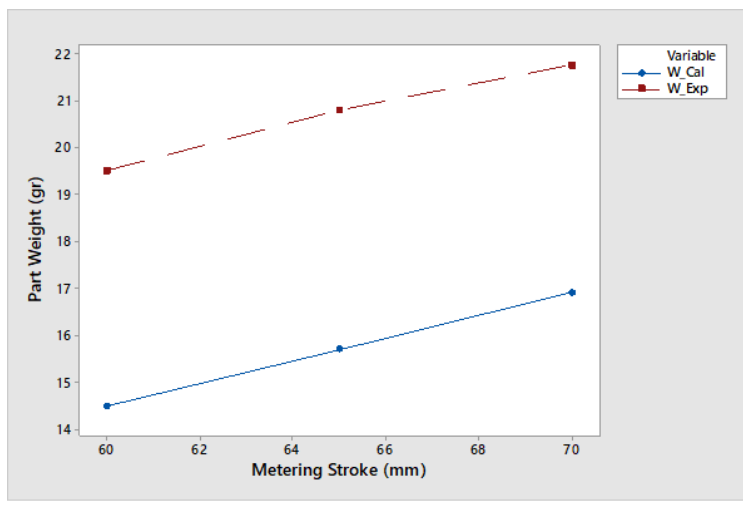

Gambar 6. Data Berat Material Hasil Perhitungan dan Percobaan
Beberapa alasan yang menyebabkan perbedaan data hasil perhitungan dan data pengukuran berat pada gambar 6. Diantaranya adalah massa jenis bahan acuan yang tidak mendekati bahan penelitian sebenarnya. Nilai $n$ pada persamaan nomor 2 tidak benar, meskipun masuk dalam kisaran data. Nilai $K$ harus diukur dan dihitung untuk mendapatkan data konduktifitas termal. Akhirnya, kelembaban produk jadi bisa ada di sana dan perlu diselidiki lebih dalam.

Selanjutnya, Tabel IV menjelaskan hasil produk Cheeck S55 BB bahwa untuk parameter uji metering stroke sebesar $60 \mathrm{~mm}$, cacat produk (NG / ditolak) berupa short-mold. Berdasarkan perhitungan rumus di atas (Persamaan 1), besarnya volume yang mengisi rongga tidak mengikuti data rekayasa, sehingga memiliki nilai massa rata-rata sebesar 19,514 gr. Sesuai dengan hasil eksperimen Widiastuti (2019). Cetakan pendek terjadi karena faktor mekanis (Penyisipan Celah) dan faktor pengaturan parameter (Gaya Penjepit, Kecepatan Injeksi, Tekanan Injeksi, Tekanan Penahan, dan Bahan Lebur Berlebih) (Widiastuti, Surbakti, Restu, Albana, \& Ihsan, 2019).

Pada parameter uji metering stroke sebesar 70 $\mathrm{mm}$, terdapat cacat produk (NG / ditolak) berupa Flashes. Meskipun cacat produk ini dapat diperbaiki dengan pemangkasan atau triming, hal ini akan menambah waktu produksi hingga waktu pengiriman produk gagal. Cacat produk, Flashes, berdasarkan hasil perhitungan rumus di atas (Persamaan 1), didapatkan besarnya volume yang mengisi rongga tidak sesuai dengan data rekayasa, sehingga memiliki nilai massa rata-rata 21.759 gr. Sesuai dengan hasil eksperimen Yanto (2018). Flashes terjadi karena faktor mekanis (Desain Gerbang; Pelepasan Gas, Perangkap Gas / Gelembung Udara) dan faktor pengaturan parameter (Suhu Cetakan, Kecepatan Injeksi, Tekanan Injeksi, Tekanan Penahan, dan Bahan Lebur) (Yanto, Saputra, \& Satoto, 2018). 
Tabel 4. Tampilan Benda Kerja Hasil Percobaan

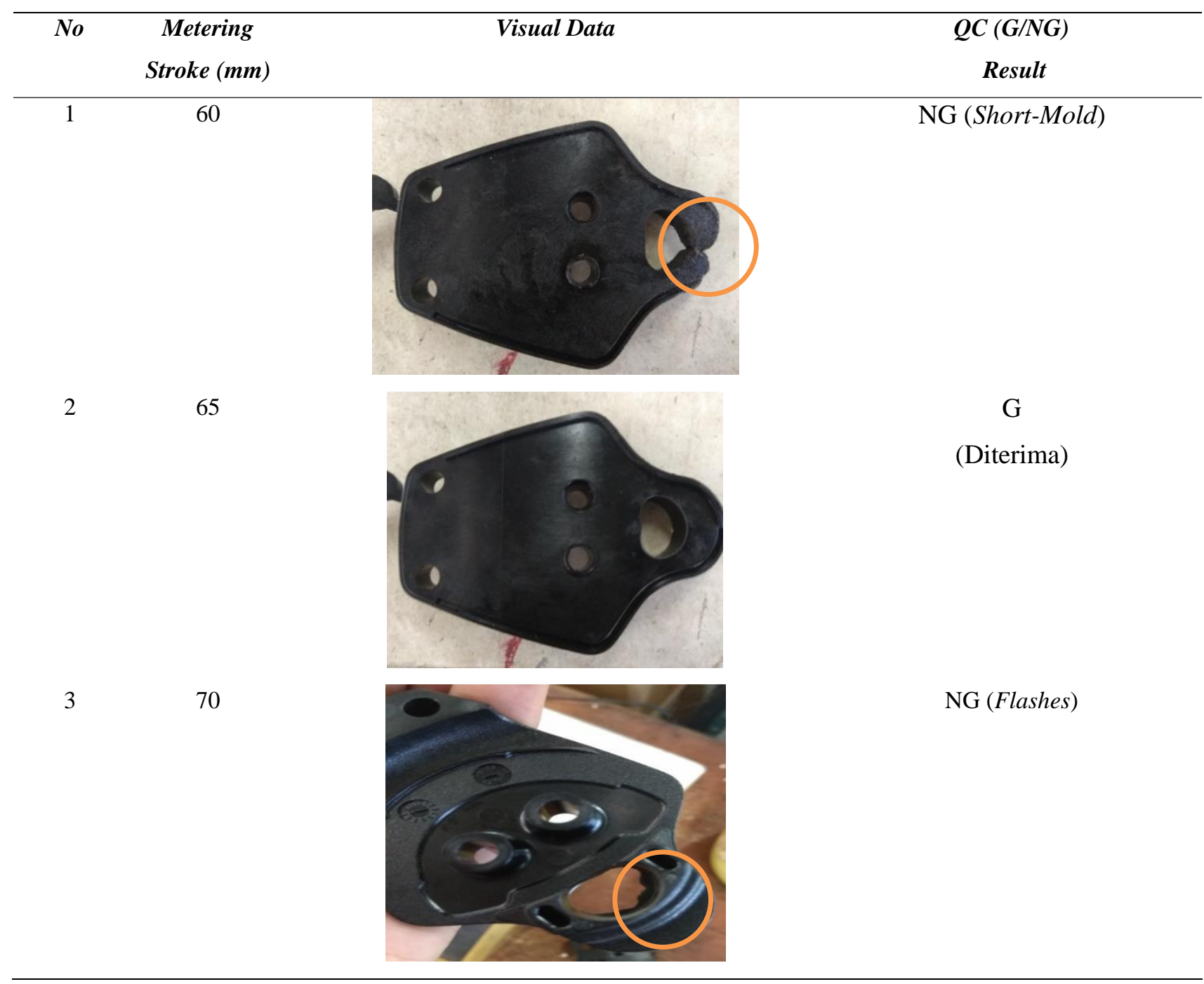

Pada Tabel 4, pada parameter metering stroke sebesar $65 \mathrm{~mm}$, hasilnya sempurna, dapat diterima, dan lolos QC Check dengan status Diterima. Itu terjadi karena parameter langkah pengukuran mengikuti rumus di atas (Persamaan 1). Volume tersebut dapat memenuhi rongga tersebut, yang memiliki nilai massa rata-rata $20.801 \mathrm{gr}$.

Gambar 7 menjelaskan masalah mekanis yang menyebabkan cetakan pendek karena celah sisipan pada garis perpisahan. Biasanya, di bawah 10.000 shot, cetakan harus diturunkan dari mesin injeksi untuk menjaga kualitas permukaan pada mold insert.

Sebaliknya, flashes terjadi karena oleh masalah mekanis. Gelembung udara merupakan masalah utama untuk mendorong material keluar dari rongga. Kapasitas rongga cetakan terganggu oleh gelembung udara yang bercampur dengan lelehan nilon 66 . Solusi untuk masalah ini adalah merancang ulang saluran pendingin cetakan dan sistem gerbang untuk mengoptimalkan pelepasan gelembung udara. Masalah ini dikategorikan pada kegagalan rekayasa kesalahan manusia.

Cacat produk lain yang disebabkan oleh kesalahan manusia atau pekerja tidak terampil adalah short-mold dan flashes. Biasanya, standar parameter pengaturan ditetapkan untuk menjaga kualitas produk. Namun kenyataannya, saat berada di bawah tekanan pekerjaan dan kondisi fisik yang tidak sehat, para pekerja mengatur parameter pengaturan berdasarkan pengalaman mereka sendiri. Pada umumnya ini terjadi pada saat mesin out-off-date dan tidak memenuhi kriteria standar. Pengaturan jam kerja, penjadwalan kegiatan family gathering, dan menjaga kompetensi pekerja merupakan alternatif dari metode penyelesaian masalah ini. 


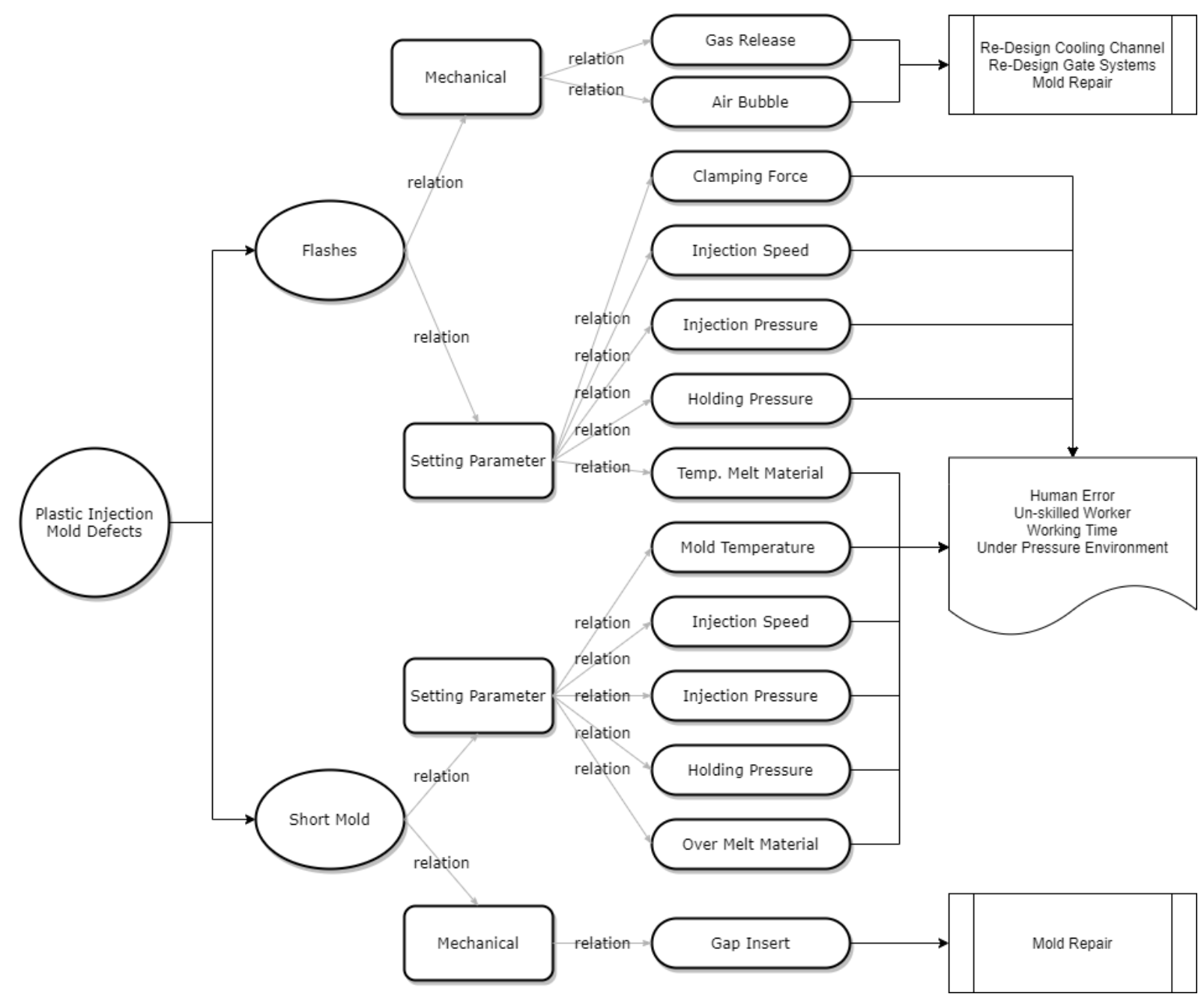

Gambar 7. Pemetaan Hubungan Sebab-Akibat Pengaturan Parameter Pada Mesin Plastic Injection Molding

\section{KESIMPULAN}

Berdasarkan data percobaan disimpulkan bahwa metering stroke sebesar $60 \mathrm{~mm}$ menyebabkan produk mengalami short-mold karena material tidak memenuhi rongga secara penuh. Metering stroke sebesar $70 \mathrm{~mm}$ menyebabkan flashing karena volume material plastik yang melebihi kapasitas cetakan rongga. Oleh karena itu, parameter pengujian produk metering stroke sebesar $65 \mathrm{~mm}$ dapat diterima dan diterima oleh QC.

Penelitian ini masih memiliki banyak pekerjaan ke depan, mengingat waktu pengambilan data yang terbatas. Tim yang terdiri dari interdisipliner ilmu dan institusi dibutuhkan untuk menggali lebih dalam untuk berkembang. Rencana kedepan diantaranya, optimasi parameter pengaturan proses produksi untuk mengurangi kerugian pada biaya produksi. Perhitungan efektifitas pekerjaan untuk meningkatkan produktivitas pekerja. Bahkan menemukan teknologi terkini yang efektif dan efisien.

\section{DAFTAR PUSTAKA}

Bryce, D. M. (1996). Plastic injection molding: manufacturing process fundamentals. Society of Manufacturing Engineers.

Chou, S., \& Chen, J. C. (2018). Six Sigma-Based Optimization of Shrinkage Accuracy in Injection Molding Processes. International Journal of Industrial and Manufacturing Engineering, 12(3), 207-212.

Firdaus, \& Tjitro, S. (2002). Studi Eksperimental Pengaruh Paramater Proses Pencetakan Bahan Plastik Terhadap Cacat Penyusutan (Shrinkage) Pada Benda Cetak Pneumatics Holder. Jurnal Teknik Mesin, 4(2), 75-80. https://doi.org/10.9744/jtm.4.2.pp.75-80

Hakim, R. (2020). Desain Cetakan Plastik Multi Cavity Dengan Sistem Intercangeable Mold Insert. Jurnal Simetris, 11(1), 23-30.

Izdihar, U. F., Budiman, J., \& Ananto, G. (2019). Analysis of Half Round Runner Dimensions Influence to Plastics Injection Results on Making Door Handle Using Taguchi Method. 
IPTEK Journal of Proceedings Series, 3, 98101.

Jahan, S. A., Wu, T., Zhang, Y., Zhang, J., Tovar, A., \& Elmounayri, H. (2017). Thermomechanical Design Optimization of Conformal Cooling Channels using Design of Experiments Approach. Procedia Manufacturing, $\quad 10, \quad 898-911$. https://doi.org/10.1016/j.promfg.2017.07.078

Moayyedian, M. (2018). Intelligent Optimization of Mold Design and Process Parameters in Injection Molding (Springer T). Australia: Springer.

Moayyedian, M., Abhary, K., \& Marian, R. (2015). Improved Gate System for Scrap Reduction in Injection Molding Processes. Procedia Manufacturing, 2(February), 246-250. https://doi.org/10.1016/j.promfg.2015.07.043

Nuruzzaman, D. M., Kusaseh, N., Basri, S., Oumer, A. N., \& Hamedon, Z. (2016). Modeling and flow analysis of pure nylon polymer for injection molding process. IOP Conference Series: Materials Science and Engineering, 114(1). https://doi.org/10.1088/1757899X/114/1/012043

Siallagan, A. S. B., Restu, F., \& Hakim, R. (2018). Experimental Study: Surface Roughness Analysis on Insert Molds with Grinding Wheel Types Variant. Proceeding of Ocean, Mechanical and Aerospace -Science and Engineering-, 5(1), 9-11.

Wahyudi, U. (2015). Pengaruh Injection Time Dan Backpressure Terhadap Cacat Injection Molding Menggunakan Material Polistyrene. Jurnal Teknik Mesin, 04(3), 81-90.

Widiastuti, H., Surbakti, S. E., Restu, F., Albana, M. H., \& Ihsan. (2019). Identifikasi Cacat Produk Dan Kerusakan Mold Pada Proses. Jurnal Teknologi Dan Riset Terapan, 1(2), 76-80.

Wijayanti, I., Hakim, R., \& Widodo. (2019). Studi Experimen Mula: Analisa Kekasaran Permukaan Baja ST 37 Terhadap Variasi Kuat Arus Listrik. Jurnal Teknologi Dan Riset Terapan, 1(2), 61-65.

Yalcin, B., \& Cakmak, M. (2004). Superstructural hierarchy developed in coupled high shear/high thermal gradient conditions of injection molding in nylon 6 nanocomposites. Polymer, 45(8), 2691-2710.

Yanto, H., Saputra, I., \& Satoto, S. W. (2018). Analisa Pengaruh Temperatur dan Tekanan Injeksi Moulding Terhadap Cacat Produk. Jurnal Integrasi, 10(1), 1-6.

Young, R. J. (1990). Handbook of plastic materials and technology (Edited by). New York: John
Wiley \& Sons Inc. 